\title{
The Role of Personal Correspondence in the Exchange of Scientific Information in Early Modern France
}

\section{J.L. PEARL}

Science has developed in an atmosphere of cooperative exchange of ideas and observations, in which questioning and argumentation has sharpened the issues. This exchange of ideas and information was one of the primary features distinguishing the scientific revolution of the sixteenth and seventeenth centuries from earlier philosophical inquiry, for which communication between scholars was of, at best, secondary importance. Virtually all historians of science in recent years have quite correctly stressed the central importance of the development of printing as an essential precondition for the scientific revolution, first for making good ancient scientific texts widely available, and then in broadcasting the innovative works of the new science.

For the scientist-philosophers of the early seventeenth century, books were only one means of communication. Many of these men, scattered all across Europe, maintained constant contact with one another by personal correspondence, which served as a vital means of rapid communication of scientific, political and personal news. They used letters to pose questions and problems which stimulated work in mathematics, physics, astronomy and medicine. As scientific journals only made their first appearance in 1665 , for the first century of the scientific revolution personal correspondence was the only means of direct exchange of ideas, information and questions, aside from printed books and pamphlets.

The importance of scientific correspondence in this period has long been recognized by most scholars in the field, and the extensive correspondence of Kepler, Galileo and Descartes, among others, have served as vital sources for the history of early European science. Recent works like the brilliant studies by Stillman Drake on Galileo and Richard Westfall on Newton have clearly demonstrated that, in order to understand the working careers of great scientists, letters, manuscript notes and drafts must be utilized along with the books they produced.

In her massive synthesis devoted to the role of printing in European 
history, Elizabeth Eisenstein takes strong issue with the emphasis on nonprinted sources. She states flatly, "Publication was indispensable for anyone seeking to make a scientific contribution."1 For her, the real centres of scientific change were the places where scientific books could be published without governmental or religious censorship; in the early seventeenth century this was England and especially the Netherlands. Eisenstein repeatedly and explicitly states that correspondence was of very limited importance: "Handwritten letters could only keep correspondents informed about their colleague's activities up to a point. Handwriting was less helpful when it came to conveying actual research results."' With letters, it was impossible, she goes on, to disseminate "hundreds of copies of a work containing lists of numbers, or diagrams, maps and charts or even precise detailed reports." 3

These opinions seriously undervalue the central role played by networks of correspondence in which scientific subjects were important. In France, in the first half of the seventeenth century, an organized system of communication of scientific information by letter came into existence that was an essential element in the dissemination and discussion of scientific developments. Contrary to Eisenstein's view, those networks of correspondence were not casual collections of "pen-pals," but formed a structured system of rapid communication in which charts, figures and diagrams were communicated, though not in hundreds of copies. Newly received letters were read aloud at gatherings of interested scholars, and copies were made and forwarded to others.

The organizers of the French correspondence system were Nicolas Fabri de Peiresc (1580-1637) and Marin Mersenne (1588-1648). The letters of Peiresc were initially published a century ago and are a rich mine for any scholar interested in the intellectual history of the early seventeenth century. This correspondence is a bit difficult to work with, partly as a result of the way it was organized by the editors, and partly because the letters themselves are rambling and unsystematic. ${ }^{4}$ As a result, Peiresc's correspondence remains sadly underutilized by historians. The letters of Peiresc's friend and colleague Father Marin Mersenne have been appearing for 50 years and should be complete within another few years. ${ }^{5}$ Mersenne's correspondence has been arranged in a strict chronological fashion and contains very extensive notes, making it much more accessible than Peiresc's while providing enough additional information to enhance the value of Peiresc's correspondence greatly. The importance of these two collections has been pointed out in a number of studies and should be increasingly recognized in the future.

Two points should be made before proceeding to an examination of the working of the French system of correspondence. In this period, almost everywhere in Europe, the censorship of books was becoming increasingly 
stringent. While it would be a mistake to exaggerate the efficiency of censorship and its effects on scientific publication, it was still a fact of life of which all intelligent men had to be aware. Letters were free from this kind of control. Thus we often see controversial subjects being discussed and opinions put forth that only appeared in published works in much more circumspect form, if they appeared at all. In Peiresc's and Mersenne's letters, for example, there are discussions on the condemnation of Galileo in 1633 of a sort that never were published in that period.

The other matter, worthy of serious study, but which can only be touched on here, is the nature of the French scientific community in this period. It was very small in numbers, made up of men scattered across the country. Some were solitary, like the Toulouse mathematician Pierre de Fermat. Fermat, incidentally, a very important figure in the development of mathematics before Descartes, never published any of his work. ${ }^{6}$ Peiresc, on the other hand, pursued his astronomical, anatomical and other researches in Aix-en-Provence in the company of a small group of interested and knowledgeable colleagues. Peiresc, Fermat, Descartes and the Dupuy brothers, Peiresc's main correspondents in Paris, were of the parlementaire class, while Gauthier, Gassendi, and Mersenne were churchmen whose occupation provided them a living and freed them from the normal social hierarchy. Because of their social and political positions, this group, as well as the friends and colleagues they could influence, could play a role in society that far outweighed their numbers. Thus I believe it is a serious mistake to associate the development and dissemination of new scientific approaches with the development of mass media. In the period we are examining, who thought something was much more important than how many people thought something.

The correspondence network I am discussing lasted over thirty years, from the 1610's to 1648, when Mersenne died. It was begun by the brilliant Provençal jurist, Nicolas Fabri de Peiresc, to keep in touch with friends from his university days in Italy, his travels in England and the Netherlands and his several years' stay in Paris. Most of the people with whom he corresponded were friends from those travels, or were introduced into the correspondence by those friends. Furthermore, many of his correspondents called on him in Provence. By 1623, Father Marin Mersenne, a Minim monk in Paris who had interests in philosophy and theology, as well as in music theory, physics and mathematics, had joined the Peiresc network, while also developing his own circle of correspondents. When Peiresc died in 1637, Mersenne assumed the role of chief coordinator and motivator of the network.

Probably because he was located in a provincial city, far from the concentrated intellectual and political excitement of Paris or Rome, Peiresc was very concerned with the establishment and maintenance of a 
reliable, quick postal system. Almost every one of his thousands of letters has a reference to the mechanics of the mail. Under good circumstances, letters took roughly twelve days between Paris and Aix. Of course, circumstances were often not good and letters were delayed or lost. In 1627, the Estates of Provence, largely through the urging of Peiresc, established a new system of regular riders to connect Aix and Lyon, so that letters could reach Paris in only six or seven days, and responses could be received only fifteen or sixteen days after sending a letter. ${ }^{7}$ A month after this was accomplished, Peiresc reported a slight delay, caused by the rider, a "gentil garçon," according to Peiresc, being badly injured when his horse fell on the ice during an unusual cold spell. ${ }^{8}$ Another time, a packet of letters for Paris was delayed, "because the courier, who perhaps didn't know how to read, thinking it would go to Paris, threw it in with those from Paris that were addressed to Dijon."

Of course this system was very fragile. It was completely disrupted within a few months of its establishment by a plague epidemic which ravaged the whole south of France from 1628 to 1630. All books and letters had to be opened and plunged into boiling vinegar to be purified, ruining or damaging many. As normal routes were closed, mail found Peiresc at his country house any way it could, and obviously much was lost. For example, he complained on 29 April 1630, "I have received your dispatch of $20 \mathrm{March}$, and am quite surprised not to find mention of I don't know how many of my letters I have written in response to yours." 10 The disruption continued after the plague burnt itself out, as Provence was torn by a nasty rebellion against Richelieu's proposed reorganization of provincial institutions that broke out late in 1630 and was not resolved until the summer of $1631 .{ }^{11}$

From Peiresc's return to Aix in 1632, until the end of his life, although he was ill most of the time, he sat on the Parlement of Provence, carried out extended astronomical observations, and conducted an innovative series of anatomical inquiries with the goal of determining how the eye worked. ${ }^{12}$ As well, he wrote long, sometimes detailed letters almost every day, complaining at one point that on one day he once wrote forty-two letters. ${ }^{13}$ He regretted not being able to write more, "For I am too small a compagnon to have the secretaries necessary to satisfy all, and too infirm to be able to do it all myself." 14 For Peiresc, though, the effort was clearly worthwhile, as he continued almost to the day of his death in reporting on observations, requesting books and exchanging news of the world.

Mersenne, in Paris, had many correspondents and friends, including Descartes, Fermat, Mydorge, Roberval, Naudé, the Pascals, Diodati, etc. He would pepper his correspondents with questions, a practice he followed for at least thirty years. Blaise Pascal wrote, "He had a talent quite his own for forming beautiful questions." 15 This could be fairly 
demanding for his correspondents. In 1626 Claude Bredeau wrote,

Since you last wrote me, I've been so troubled by head, chest and stomach pains that I have been totally useless. I am now a bit relieved of those pains, except for the shortness of breath that will go with me to the grave, of weakness of feet to travel, of the hand to write, of the ear to hear and of weakness of the sight to see. I need over an hour after the sun is up before I can read or write, and cannot read or write for an hour before the sun goes down, even with glasses. I can do nothing by candlelight. My memory and thoughts are also weak. See how it is possible for a man in this condition to respond to your questions!

Bredeau then went on to write some 5,000 words on many points, all in response to questions posed by Mersenne. ${ }^{16}$

Mersenne maintained a twenty-five year correspondence with Descartes, who wrote almost every week. At one point, in 1629, Descartes asked very politely if Mersenne could stop asking so many questions, since answering them took so much time and attention. ${ }^{17}$ Several months later, Descartes wrote "You interrogate me as if I should know everything, and seem to have forgotten what you promised me. ..."18 However, in both these letters, Descartes still answered Mersenne's questions on mathematics, physics, music and philosophy, as he continued to do for almost twenty more years.

In a field developing in the way that mathematics was in this period, a correspondence such as that managed by Mersenne between Descartes, Roberval, Fermat and others was probably the only way that complex specific problems could be dealt with by scholars separated by hundreds of miles. Books took too long to publish, and could only show one view at one point in its development. The mathematical arguments of this group were lively, sometimes rancourous, and very significant in the rapid development of the field.

Mersenne also used letters in an attempt to conquer confessional boundaries. In 1634 he wrote the Protestant professor André Rivet, "It is a great pity to see that the inclination of things engenders so many quarrels over religion. I pray to God that we can raise ourselves to a high enough level so that our ignorance disappears, and that as God is all in all, we can unite with each other in a real love and a relationship that no one can take away."19 In 1638, Mersenne asked Rivet, "I would like to know if you believe that the opinion of the movement of the earth and the stability of the sun is heresy and against Scripture." ${ }^{20}$ A month later, Mersenne answered Rivet's response, "You are correct in not holding the movement of the Earth as heresy, for Holy Scripture was not made to teach us philosophy or mathematics." 21

Elizabeth Eisenstein buttresses her argument on the preeminence of 
print by stating that large-scale cooperative scientific efforts were only possible through the agency of print. She states,

In 1631, Gassendi, following a suggestion made by Kepler, published an open letter to the astronomers of Europe, asking them to observe the transit of Mercury across the sun and noting it was due to take place on November 7, 1631. Here is an example of a collaborative effort in simultaneous observation that was made possible by print and had been impossible in the age of scribes. $\mathrm{He}$ also published a pamphlet in 1632 which informed the reading public of his findings, outlined Kepler's theory and referred interested readers to Kepler's publications for further details. ${ }^{22}$

Pierre Gassendi was a brilliant scientist-philosopher who had a keen sense of the value of the press. But he would have been very surprised at the above statement. Peiresc, Gassendi's patron, friend and colleague, had already done what Eisenstein states was impossible, and continued to do so, with Gassendi's collaboration. In January of 1628 , Peiresc organized, by letter, simultaneous observations of a lunar eclipse from Paris, Aix and Digne, in order to obtain accurate measurements for the longitudes of Aix and $P$ aris. This effort was a success and provided a much more accurate longitude for Aix than had previously been known. ${ }^{23}$

Peiresc immediately set to work organizing much larger ventures. In a letter to the Dupuys in Paris, he wrote, "Because in two years or so there will be an eclipse of the sun, I must put into the Cardinal's (Barberini) head to command, through the general of the Jesuits and other orders who have monks versed in mathematics in several places of the world, to command them to make observations everywhere that it appears, and to prepare for this a small questionnaire on what is necessary, and the instruments necessary to do this, with the goal of establishing the true longitudes of the places of their residence, at least for those of Europe, Constantinople, Jerusalem, Alexandria and other well-known places of antiquity." ${ }^{24}$ This effort fell through because of the troubles discussed earlier, but for a lunar eclipse in August 1635, Peiresc organized, instructed and supplied instruments to a network of observers all over the world, including Paris, Aix, Rome, Naples, Cairo, Aleppo and Quebec. ${ }^{25}$ This observation paid an outstanding dividend: Peiresc showed that the Mediterranean was actually one thousand kilometres shorter than the ancients had believed, and maps were, over time, corrected accordingly. ${ }^{26}$

At this very time, Peiresc, in an effort to understand how vision worked in relation to telescopic observations, conducted a long series of dissections of animal, and eventually human, eyes. He wrote long and detailed reports to his Paris correspondents, often immediately following the dissection. These letters were read aloud, and copies were made and forwarded to those interested in these inquiries. These reports, though 
never printed, reached a significant, select audience, and should be regarded as published.

Running through these scientific letters there is a sense of real excitement at the discoveries being made daily. One example will suffice. In September, 1634, Peiresc wrote to Bourdelot that he and Gassendi had been working closely together on a series of anatomical observations:

We have just seen the lacteal veins of the body of a man an hour and a half after
he had been hanged, the body having been given by the Court (of which Peiresc
was a member) to the medical professors with permission to open it up the
same day. It is true that I had ordered the jailer to feed him well before he knew
of his condemnation and that I had warned the master surgeon who did the
dissection, to open the body immediately and quickly (to get to) the veins and
arteries into the liver, to avoid the lacteals emptying too quickly, as I had
proved previously with a sheep, which he did very happily in a full theatre in
the presence of over 30 honorable persons... ${ }^{27}$

Thus a full report of a significant discovery was disseminated and could be read within days of the actual dissection.

There is nothing in my argument that attempts to diminish the tremendous impact of print on the intellectual and social history of Europe, or of the importance of books in the transmission of scientific ideas and information. Mersenne, after all, published a long list of books. Peiresc was a great collector of books and encouraged others to publish, even sending Mersenne money to help him underwrite the costs of publication. Furthermore, there can be no doubt that letters had their limitations: they could not broadcast scientific ideas to a wide reading public, they were expensive to send and often were delayed or lost. And we do, in letters, encounter remarks like, "But this is too long a discourse on this subject for a letter, in matters that cannot be explained in a few words. I ask you to read my book attentively." 28 And, of course, many of Mersenne's correspondents complained about his terrible handwriting as much as they did about his incessant questioning.

But letters in the organized networks of correspondence I have been describing were an essential aspect of scientific communication at this time. They were the best means for rapid reports, debates on specific issues and problems, organization of simultaneous and comparative observations and experiments, and for the conducting of the politics of ideas. Mersenne dreamt that, through letters, a great scientific academy could be organized for the sharing of ideas. In the midst of the disruption caused by the thirty-years' war, he wrote to Peiresc, "I wish we had peace so that we could establish an Academy, not in one city alone like we have here and elsewhere, if not for all of Europe, at least for all of France, which would have its communications by letters which would often be more valuable 
than conferences where people often become too heated in contesting the opinions that are proposed, which turn many away."29

By the time of Mersenne's death in 1648, France was well on the way to establishing a real academy of sciences which, in league with the other academies of Europe, made his dream come true.

\section{University of Toronto}

\section{Notes}

1 Elizabeth Eisenstein, The Printing Press as an Agent of Change, 2 vols. (Cambridge University Press, 1979), p. 694.

2 Ibid., p. 460.

3 Ibid., p. 461.

4 Peiresc's correspondance has been published in several separate collections. The largest is $L a$ Correspondance de Peiresc, ed. Ph. Tamizey de Larroque, 7 vols. (Paris, 1888-1898). Another collection is Correspondants de Peiresc, ed. Tamisey de Larroque, 2 vols. 1879-1879 (Geneva: Slatkin Reprints, 1972), also Peiresc, Lettres à Malherbe, ed. Raymond Lebèque, (Paris, 1976).

5 Marin Mersenne. Correspondance de Marin Mersenne, first volume (1932) ed. Tannery \& de Waard. now being edited by Armand Bealieu.

6 See: Michael Mahoney, The Mathematical Career of Pierre de Fermat (1601-1655) (Princeton University Press, 1973).

7 Peiresc to Dupuy, 16 November 1627, Peiresc Correspondance, 1:439. Dupuy, ibid., 1:439.

8 Peiresc to Dupuy. 29 January 1628, ibid., I:513.

9 Peiresc to Dupuy, 26 June 1634. ibid., 3:133.

10 Peiresc to Dupuy, 29 April 1630, ibid. . 2:237.

11 On the rebellion in Aix, see my Ph.D. Thesis, Guise and Provence (Northwestern University, 1968); Renè Pillorget, Mouvements Insurrectionels en Provence entre 1596 et 1715 (Paris, 1975); Sharon Kettering,Judicial Politics and Urban Revolt in Seventeenth Century France (Princeton University Press, 1978).

12 See my article "Peiresc and the Search for Criteria of Scientific Knowledge," Proceedings of the Western Society for French History (1978).

13 Pierre Humbert, Un Amateur: Peiresc, (Paris, 1933), p. 190.

14 Peiresc to Dupuy, 15 October 1635, Peiresc, Correspondance 3:390.

15 Mersenne Correspondance, introduction, 1:x1 vii.

16 Bredeau to Mersenne, 23 February 1626, ibid., 1:380.

17 Descartes to Mersenne, 8 October 1629, ibid., 2:299.

18 Descartes to Mersenne, 25 February 1630, ibid., 2:392.

19 Mersenne to Rivet, 12 March 1634, ibid., 4:71-2.

20 Mersenne to Rivet, 20 November 1638, ibid., 8:222.

21 Mersenne to Rivet, 20 December 1638, ibid., 8:238.

22 Eisenstein, Printing Press, p. 631.

23 Peiresc to Holstenius, 28 May 1628, Peiresc, Correspondance 5:274.

24 Peiresc to Dupuy, 4 March 1628, ibid., 1:548.

25 Bibliotheque Inguimbertine, Carpentrias, vol. 1832, fol. $24 \mathrm{ff}$.

26 Humbert, Peiresc, p. 224.

27 Peiresc to Bourdelot, 6 September 1634, Peiresc, Correspondance 7:712.

28 Doni to Mersenne, May 1636, Mersenne Correspondance 6:78.

29 Mersenne to Peiresc, 15 July 1635, Peiresc, Correspondance 2:560. 